\title{
Implementasi Media Audio-Visual dalam Pembelajaran Istima‘
}

\author{
Rizka Sari, Muassomah \\ Universitas Islam Negeri Maulana Malik Ibrahim Malang \\ Corresponding author: rizkasari381@gmail.com
}

\begin{abstract}
Listening is a basic human ability which is possessed from the beginning of his birth until throughout his life. However, at the level of language learning there is a low level of student interest in learning specifically. For this reason, this study aims to describe the process of implementing the Audio-visual method in special learning for thirdsemester students of Arabic education at the Bani Fatah Islamic Institute in Jombang. This type of research is a qualitative descriptive study using observation and documentation instruments. The subject and object of this research are the third semester students of Arabic education at the Bani Fatah Islamic Institute in Jombang. The results of this study indicate, istima 'learning process with audio-visual methods that have been arranged very well, namely: a) lecturer planning by preparing appropriate material b) students listening to the video being watched c) students write mufrodat known based on video d) students conclude the story in the video using Arabic e) students take wisdom from the video watched f) evaluation in this study is divided into two: first, written evaluation (students collect mufrodat notes of listening results), second, oral evaluation (students directly speak Arabic in giving conclusions and lessons from the video). In implementing learning specifically using this audio-visual method, it has changed the atmosphere of learning more interesting and increased the activeness of students in learning.
\end{abstract}

Mendengar merupakan kemampuan dasar manusia yang dimiliki pada awal kelahirannya sampai sepanjang hidupnya. Namun pada tatarannya, pembelajaran bahasa terjadi rendahnya minat belajar mahasiswa pada pembelajaran istima'. Karena itulah, penelitian ini 
bertujuan untuk mendeskripsikan proses implementasi metode Audio-visual dalam pembelajaran istima' pada mahasiswa semester tiga pendidikan bahasa Arab di Institut Agama Islam Bani Fatah Jombang. Jenis penelitian ini adalah deskriptif kualitatif dengan menggunakan instrumen penelitian observasi dan dokumentasi. Subjek dan objek penelitian ini adalah mahasiswa semester tiga pendidikan bahasa Arab di Institut Agama Islam Bani Fatah Jombang. Hasil penelitian ini menunjukkan, proses pembelajaran istima' dengan metode audio-visual yang telah disusun dengan sangat baik, yaitu : a) perencanaan dosen dengan menyiapkan materi yang sesuai b) mahasiswa menyimak video yang dipertontonkan c) mahasiswa menulis mufrodat yang diketahui berdasarkan video d) mahasiswa menyimpulkan cerita dalam video dengan menggunakan bahasa arab e) mahasiswa mengambil hikmah dari video yang ditonton f) evaluasi dalam penelitian ini terbagi dua : pertama, evaluasi tulisan (mahasiswa mengumpulkan catatan mufrodat hasil menyimak), kedua, evaluasi lisan/syafahy (mahasiswa secara langsung berbahasa arab dalam memberi kesimpulan dan hikmah dari video). Dalam pelaksanaan pembelajaran istima' menggunakan metode audiovisual ini, telah mengubah suasana pembelajaran lebih menarik dan meningkatkan keaktifan mahasiswa dalam pembelajaran.

Keywords: audio-visual; implementation; istima'; listening learning.

\section{Pendahuluan}

Dalam pembelajaran bahasa, khususnya dalam Bahasa Arab ada beberapa terminologi yang harus di ketahui oleh pengajar. Terminologi ini menjadi penting untuk di ketahui oleh pendidik karena sebagai bekal baginya dalam mendidik. Zulhanan (2014: 121) menyebutkan bahwa dalam pembelajaran khususnya bahasa Arab, ada beberapa terminologi yang perlu diketahui, diantaranya adalah empat ketrampilan berbahasa, partikulasi bahasa Arab, pendekatan, metode, teknik, dan media pembelajaran. Jadi terminologi pembelajaran Bahasa Arab ini tidak bisa di pisahkan dan saling berhubungan dalam pembelajaran bahasa arab. Sebagai contoh jika guru hanya menguasai ketrampilan kebahasaan 
akan tetapi tidak menguasai metode pembelajaran otomatis tidak akan terjadi pembalajaran yang kondusif (Miftahul Mufid, 2018: 91).

Pembelajaran mahārah al-istimā' adalah proses kegiatan yang terencana dengan tujuan untuk meningkatkan kemampuan seseorang dalam mencerna atau memahami kata atau kalimat yang diujarkan oleh mitra bicara atau media tertentu, sehingga siswa mampu membedakan bunyi-bunyi bahasa Arab secara benar serta memahami apa yang didengar (fahm al-masmū') dan mampu mendeskripsikan serta menjelaskan kepada orang lain apa yang didengar dengan benar dan tepat (Acep Hermawan, 2011: 130). Guru mengajar bahasa Arab dengan tidak menggunakan metode yang variasi sehingga membuat siswa tidak aktif dalam menyimak. Di samping itu, mereka hanya menggunakan papan tulis dan suara guru sendiri serta buku teks sebagai media pembelajaran, padahal di lembaga tersebut terdapat laboratorium bahasa, LCD, proyektor, dan komputer yang yang seharusnya dapat difungsikan untuk pembelajaran bahasa Arab.

Berdasarkan permasalahan tersebut, penulis menganggap bahwa sangat penting untuk melakukan penelitian yang berkaitan dengan permasalahan di atas, sehingga untuk mengeliminir permasalahan tersebut penulis ingin mengimplementasi metode audio-visual dalam pembelajaran mahārah al-istimä'. Dengan mengimplementasi metode audiovisual dalam pembelajaran mahārah al-istimā'diharapkan dapat membantu dosen dan mahasiswa dalam pembelajaran mahārah al-istimā'di Institut Agama Islam Bani Fatah Jombang. Adapun penelitian-penelitian yang terdahulu lebih fokus kepada efektivitas, aktivitas, hasil belajar, ataupun kreativitas yang belum maksimal dimana hal ini perlu adanya inovasi baru dalam pembelajaran istima' sehingga proses pembelajaran terbilang menarik dan lebih menggugah 
semangat peserta didik. Adapun tulisan yang sederhana ini merupakan pelengkap dari penelitian-penelitian sebelumnya dengan mengimplementasikan metode audio-visual dalam pembelajaran istima' di tingkat universitas. Yang berfokus untuk mengetahui proses pembelajaran istima' dan cara mengimplementasikan metode audio-visual pada mahasiswa semester tiga pendidikan bahasa Arab di Institut Agama Islam Bani Fata Jombang. Adapun rumusan masalah pada penelitian ini adalah bagaimana proses pembelajaran istima' dan cara mengimplementasikan metode audio-visual pada mahasiswa semester tiga pendidikan bahasa Arab di Institut Agama Islam Bani Fata Jombang?

Menurut hemat penulis bahwa metode audio-visual merupakan metode yang tepat untuk pembelajaran istima'. Dan metode ini bagi mahasiswa sangat cocok karena disajikan dalam bentuk surara dan gambar sehingga informasi atau materi yang disampaikan mudah difahami. tentu, ini hal yang baru dalam pembelajaran istima' sehingga tulisan yang sederhana ini dapat bermanfaat dan menambah khzanah pengetahuan dan pengembangan metode pembelajaran bahasa Arab khususnya.

\section{Metode}

Penelitian ini termasuk dalam jenis penelitian deskriptif kualitatif dengan pendekatan studi lapangan yaitu suatu penelitian yang berusaha menggambarkan keadaan yang sebenarnya dilapangan dengan menggunakan metode kualitatif. Metode kualitatif salah satu metode penelitian yang bertujuan untuk mendapatkan pemahaman tentang kenyataan melalui proses berpikir induktif. Melalui penelitian kualitatif peneliti dapat mengenali subjek, merasakan apa yang mereka alami dalam kehidupan sehari-hari.

Dalam penelitian ini peneliti bertindak sebagai instrument utama (human instrument), artinya penelitilah yang 
mengumpulkan data, menganalisis data, dan menyimpulkan hasil penelitian. Dalam penelitian ini, peneliti terlibat dalam situasi dan setting fenomena yang diteliti. Penelitian ini menggunakan pendekatan kualitatif melalui observasi dan dokumentasi. Observasi dilakukan tidak terbatas pada orang, tetapi juga dengan obyek-obyek alam lain (Fika Vindayani, 2019). Teknik pengumpulan data yang digunakan adalah observasi dan dokumentasi.

Tujuan penelitian ini adalah untuk mendeskripsikan proses dan cara mengimplementasikan metode audio-visual dalam pembelajaran Istima' pada mahasiswa semester tiga pendidikan bahasa Arab di Institut Agama Islam Bani Fatah Jombang. Dalam penelitian ini terdapat sumber data primer yaitu data yang langsung didapat oleh peneliti dari lapangan. Dan adapun sumber data sekunder yaitu buku-buku atau literasi-literasi yang berkenaan dengan judul penelitian. Populasi dan sampel penelitian adalah mahasiswa semester tiga Pendidikan Bahasa Arab Institut Agama Islam Bani Fatah Jombang yang berjumlah 16 mahasiswa . Waktu dan tempat penelitian adalah bulan oktober 2019 di Institut Agama Islam Bani Fatah Jombang.

\section{Hasil dan Pembahasan}

Metode adalah cara yang digunakan untuk mencapai tujuan yang telah ditetapkan (Muhammad Afandi, 2013: 16). Wirna Sanjaya (2008: 147), menyatakan bahwa metode adalah cara yang digunakan untuk mengimplementasikan rencana yang sudah disusun dalam kegiatan nyata agar tujuan yang telah disusun tercapai secara optimal Ini berarti metode digunakan untuk merealisasikan proses belajar mengajar yang telah ditetapkan. Di dalam Kamus Besar Bahasa Indonesia (KBBI) (2019) metode merupakan suatu cara yang digunakan dalam melaksanakan sutua pekerjaan agar tercapai sesuai dengan yang diinginkan. Sedangkan metode menurut Sudjana 
(2002: 76) ialah cara yang digunakan oleh seorang guru dalam mengadakan pembelajaran yang berhubungan langusng dengan siswa.

Dari beberapa definisi di atas dapat disimpulkan bahwa metode merupakan cara yang digunakan oleh guru untuk mennyampaikan materi dengan sistematis agar tercapai tujuan yang diinginkan. Atau dengan ungkapan lain bahwa metode ialah cara yang dipilih oleh seorang pengajar untuk mengoptimalkan proses pembelajaran yang bertujuan mencapai tujuan pembelajaran yang diinginkan. Atau lebih singkatnya metode merupakan suatu alat dalam pelaksanaan pendidikan, yakni yang digunakan dalam penyampaian materi tersebut. Materi pelajaran yang mudah pun kadang-kadang sulit berkembang dan sulit diterima oleh peserta didik, karena cara atau metode yang digunakannya kurang tepat. Namun, sebaliknya suatu pelajaran yang sulit akan mudah diterima oleh peserta didik, karena penyampaian dan metode yang digunakan mudah dipahami, tepat dan menarik.

Sedangkan Siti Maesaroh (2013: 155) mengemukakan bahwa metode pembelajaran merupakan suatu alat pelaksanaan pendidikan yang digunakan dalam menyampaikan materi. Dedy Yusuf Aditya (2016: 167) berpendapat bahwa metode adalah suatu cara atau strategi yang dilakukan oleh seorang guru agar terjadi proses belajar pada diri mahasiswa untuk mencapai tujuan. Menurut Abdurrahman Ginting (2008: 42), metode pembelajaran dapat diartikan cara atau pola yang khas dalam memanfaatkan berbagai prinsip dasar pendidikan serta berbagai teknik dan sumberdaya terkait lainnya agar terjadi proses pemblajaran pada diri pembelajar. Dengan kata lain, metode pembelajaran adalah teknik penyajian yang dikuasai oleh seorang guru untuk menyajikan materi pelajaran kepada murid di dalam kelas baik secara individual atau secara kelompok agar materi 
pelajaran dapat diserap, dipahami dan dimanfaatkan oleh murid dengan baik.

Menurut Sadiman dalam bukunya Media Pendidikan (1996: 6) media adalah berbagai bentuk perangkat yang dapat menyajikan pesan serta merangsang peserta didik untuk belajar. Arsyad, (2014: 4) secara implisit mengatakan bahwa media pembelajaran meliputi alat yang secara fisik digunakan untuk menyampaikan isi materi pengajaran, yang terdiri dari antara lain buku, tape recorder, kaset, video camera,video recorder, film, slide (gambar bingkai) foto, gambar, grafik, televisi, dan komputer. Pendapat lain disampaikan oleh Sumiati (2008: 162), bahwa media pembelajaran mempunyai 3 bentuk atau format, yaitu suara (audio) bentuk (visual) dan gerak (motion). Rusman., dkk. (2011: 128) mengemukakan bahwa "video merupakan serangkaian gambar gerak disertai suara yang membentuk satu kesatuan rangkaian menjadi sebuah alur, dengan pesan-pesan didalamnya untuk ketercapaian tujuan pembelajaran, yang disimpan dalam media pita dan disket". Video banyak digunakan dalam pembelajaran interaktif, dan dijelaskan oleh Arsyad (2014: 4) bahwa media pembelajaran interaktif merupakan sistem penyampaian pengajaran yang menyajikan materi video rekaman dengan pengendalian komputer kepada penonton (peserta didik) yang tidak hanya pasif mendengar dan melihat video dan suara, tetapi juga aktif memberikan respon, dan respon peserta didik tersebut akan menentukan kecepatan dan sekuensi penyajian materi.

Audio visual adalah video yang menampilkan bentuk suara dan gambar (Lidya Fita Kusumadewi \& S. Suharto, 2010: 2). Metode audio visual yaitu : suatu cara menyajikan bahan pelajaran dengan menggunakan alat-alat media pengajaran yang dapat memperdengarkan, atau memperagakan bahanbahan tersebut sehingga siswa/murid-murid dapat menyaksi- 
kan secara langsung, mengamat-amati secara cermat, memegang / merasakan bahan-bahan peragaan itu (Muhammad Mas'ud, 2014: 1). Pada setiap kali penyajian bahan pelajaran semestinya guru menggunakan media pengajaran, seperti lembaran balik, papan planel, proyektor, dan lain sebagainya. Metode audio visual dikenal dengan keharusan penggunaan audio visual aids atau audio visual material. Ketiga istilah (baik audio visual aids, audio visual material, maupun audio visual method) sama-sama menekankan kepada pemberian pengalaman secara nyata kepada anak didik (M. Abdul Hamid, dkk, 2008: 69). Dengan melihat langsung, mendengar, meraba, mencium jika perlu, tentang hal-hal yang dipelajari itu. Jadi inti pengajaran audio visual ini adalah dipergunakan beberapa alat/bahan media pengajaran antar lain melalui film strip, radio, TV, piringan hitam, tape recorder, gambar-gambar peta, dan lain-lain sebagainya. Lebih utama menggunakan bendabenda asli sebagai peraga.

Menurut M. Khalilullah (2013: 34), kelebihan metode audio visual yaitu: a. Siswa dapat menyaksikan, mengamati serta mengucapkan langsung sekaligus. b. Dengan memeragakan bendanya secara langsung tersebut, hal ini sangat menarik perhatian siswa. c. Pengetahuan siswa menjadi inegral, fungsional dan dapat terhindar dari pengajaran verbalisme. $d$. Pengajaran menarik minat dan perhatian siswa. Dan kekurangan metode audio visual: a. Memerlukan waktu dan perencanaan yang matang. b. Tugas guru menjadi berat, sebab disamping harus merencanakan materi pelajaran yang akan disajikan juga harus menguasai berbagai alat sarana peragaan/media pengajaran berbagai alat sarana peragaan serta alat komunikasi lainnya. c. Pengadaan alat sarana peragaan memerlukan biaya dan pemeliharaan yang cukup memadai. d. Kecenderungan menganggap bahwa pengajaran melalui berbagai macam alat / media pengajaran bersifat pemborosan, bahkan memakan/ menyita waktu yang banyak. 
Pembelajaran adalah proses mengatur, mengorganisasi lingkungan yang ada di sekitar peserta didik sehingga dapat menumbuhkan dan mendorong peserta didik melakukan proses pembelajaran (Muhammad Darwis Dasopang, 2017: 337). Sedangkan menurut Undang-Undang Republik Indonesia nomor 20 tahun 2003 tentang sistem pendidikan nasional bahwa pembelajaran adalah proses interkasi peserta didik dengan peserta didik lainnya dan sumber belajar yang berlangsung dalam suatu lingkungan belajar (Republik Indonesia, 2003: 6).

Mahārah al-istimā' terdiri dari kata mahārah dan alistimā',kata mahārah merupakan masdar dari maharayamharu-mahāratan yang berarti mengendalikan sehingga menjadi pandai. Secara etimologis al-istimä' dapat diartikan mendengarkan dengan penuh perhatian (Ahmad Warson Munawwir, 2002: 1363). Para ahli lingustik membedakan antara mendengar (as-simā'), menyimak (al-istimā), dan mendengar dengan serius (al-inșāt).Mendengar (as-simā') hanyalah menerima suara yang tanpa adanya perhatian dan unsur kesengajaan, seperti suara bising atau hiruk pikuk di jalan raya. Sedangkan menyimak (al-istimā') adalah menuntut adanya kesengajaan dan perhatian dalam mendengarkan segala sesuatu, dan mendengar dengan serius (al-inșāt) adalah tingkatan lebih di atas menyimak yang menuntut konsentrasi dan perhatian yang lebih pada pembicaraan si penutur (Abdul Wahab Rosyidi, 2009: 84). Mahārah al-istimā' adalah kemampuan seseorang dalam mencerna atau memahami kata atau kalimat yang diujarkan oleh mitra bicara atau media tertentu.Kemampuan ini sebenarnya dapat dicapai dengan latihan yang terus menerus untuk mendengarkan perbedaanperbedaan bunyi unsur-unsur kata dengan unsur lainnya menurut makhārijul hurūfyang betul baik langsung dari penutur aslinya maupun melalui rekaman (Acep Hermawan , 2011: 130). 
Berdasarkan uraian singkat tersebut di atas yang dimaksud dengan materi pembelajaran mahārah al-istimā' adalah bahan ajar yang digunakan dalam proses pembelajaran yang terencana dengan tujuan untuk meningkatkan kemampuan seseorang dalam mencerna atau memahami kata atau kalimat yang diujarkan oleh mitra bicara atau media tertentu. Keterampilan ini dapat dicapai dengan latihan yang terus menerus untuk mendengarkan perbedaan-perbedaan bunyi unsur-unsur kata dengan unsur-unsur lainnya menurut makhārijul hurūf yang betul dan baik langsung dari penutur asli maupun melalui rekaman, sehingga siswa mampu membedakan bunyi-bunyi bahasa Arab secara benarketerampilan yang menggunakan indra pendengaran ini juga memusatkan perhatian kepada objek yang didengar kemudian mampu memahami apa yang di dengar (fahm almasmū') dan mampu mendeskripsikan serta menjelaskan kepada orang lain apa yang didengar dengan benar dan tepat.

Dalam penelitian yang dilaksanakan pada mahasiswa pendidikan bahasa Arab semester tiga Institut Agama Islam Bani Fatah Jombang, peneliti mengimplementasikan metode audio-visual dengan tiga langkah:

\section{Langkah Persiapan}

Dalam langkah persiapan ada beberapa hal yang perlu dilakukan peneliti, di antaranya adalah sebagai berikut: 1) Menyiapkan mental mahasiswa agar dapat berperan serta secara aktif, sehingga paling lambat sehari sebelumnya rencana kegiatan pembelajaran dengan memanfaatkan media audio harus sudah diberitahukan kepada mereka. 2) Pastikan bahwa peralatan yang akan digunakan untuk menampilkan proyektor dan speaker dapat berfungsi dengan baik. 3) Pastikan bahwa di ruangan tempat kegiatan pembelajaran tersedia power listrik yang dibutuhkan untuk memutar program. 4) Ruangan hendaknya sudah diatur sedemikian 
rupa (cahaya, ventilasi, pengaturan tempat duduk, ketenangan dan lain-lain) sehingga mahasiswa dapat mengikutinya dengan nyaman. 5) Jika memerlukan Lembar Kerja Siswa atau bahan penyerta, pastikan bahwa keduanya telah tersedia dengan jumlah yang mencukupi.

\section{Langkah Pelaksanaan}

Dalam langkah pelaksanaan ada beberapa hal yang perlu dilakukan peneliti, di antaranya adalah sebagai berikut: Pertama, perencanaan dosen dengan menyiapkan materi yang sesuai. Kedua, mahasiswa menyimak video yang dipertontonkan. Ketiga, mahasiswa menulis mufrodat yang diketahui berdasarkan video. Keempat, mahasiswa menyimpulkan cerita dalam video dengan menggunakan bahasa arab. Kelima, mahasiswa mengambil hikmah dari video yang ditonton. Keenam, evaluasi dalam penelitian ini terbagi dua : pertama, evaluasi tulisan / tahriry ( mahasiswa mengumpulkan catatan mufrodat hasil menyimak), kedua, evaluasi lisan / syafahy ( mahasiswa secara langsung berbahasa arab dalam memberi kesimpulan dan hikmah dari video).

\section{Langkah Tindak Lanjut}

Pada langkah tindak lanjut hal-hal yang harus dilakukan antara lain sebagai berikut: 1) Mintalah mahasiswa untuk menceritakan ringkasan materi pembelajaran yang berhasil mereka serap selama mendengarkan program media audio. 2) Mintalah mahasiswa untuk menanyakan berbagai hal yang dianggap sulit (yang berhubungan dengan materi pembelajaran yang baru saja mereka pelajari melalui media audio). 3) Sebelum pendidik menjawab pertanyaan-pertanyaan yang diajukan oleh peserta didik, terlebih dahulu berikan kesempatan kepada sesama peserta didik untuk mendiskusikan jawabannya. Peran pendidik di sini adalah sebagai fasilitator. 4) Jika 
semua pertanyaan sudah berhasil dijawab oleh teman-teman sesama peserta didik, maka pendidik tidak perlu menjawabnya lagi. Tugas pendidik adalah sebatas menjawab pertanyaan-pertanyaan yang belum terjawab selama berlangsungnya diskusi. 5) Berikan tes untuk mengukur tingkat keberhasilan peserta didik dalam mengikuti kegiatan pembelajaran melalui pemanfaatan media audio.

Berdasarkan hasil penelitian yang telah peneliti lakukan bahwa proses pembelajaran istima' pada mahasiswa semester tiga pendidikan bahasa Arab di Institut Agama Islam Bani Fatah Jombang, sebagai berikut:

\begin{tabular}{cl}
\hline No & \multicolumn{1}{c}{ Indikator } \\
\hline 1. & $\begin{array}{l}\text { Mahasiswa menonton video yang berjudul "Amal” } \\
\text { dengan durasi 4 menit. }\end{array}$ \\
\hline 2. & $\begin{array}{l}\text { Mahasiswa mendengarkan pemutaran video } \\
\text { sebanyak 3 kali. }\end{array}$ \\
\hline 3. & $\begin{array}{l}\text { Setelah menyimak video, mahasiswa mencatat } \\
\text { mufradat yang dapat ditangkap. }\end{array}$ \\
\hline 4. & $\begin{array}{l}\text { Mahasiswa menyebutkan mufradat yang telah } \\
\text { mereka tulis. }\end{array}$ \\
\hline 5. & $\begin{array}{l}\text { Mengungkapkan kembali kisah dari video dan } \\
\text { mengambil hikmahnya dengan diskusi } \\
\text { menggunakan bahasa Arab. }\end{array}$ \\
\hline
\end{tabular}

Berdasarkan tabel di atas, video yang dipilih adalah berbentuk kisah/cerita. Karena penyajiannya dengan metode audio-visual maka akan lebih mudah dipahami dibandingkan mendengarkan audio saja dengan fasilitas yang kurang mendukung.

Adapun cara mengimplementasikan metode audio-visual dalam pembelajaran Istima' pada mahasiswa semester tiga 
pendidikan bahasa Arab di Institut Agama Islam Bani Fatah Jombang

\begin{tabular}{cl}
\hline No & \multicolumn{1}{c}{ Langkah-langkah } \\
\hline 1. & $\begin{array}{l}\text { Dosen menyiapkan video yang telah dipilih dan } \\
\text { dipertontonkan kepada mahasiswa }\end{array}$ \\
\hline 2. & $\begin{array}{l}\text { Mahasiswa mendengarkan video dengan cermat } \\
\text { dan teliti }\end{array}$ \\
\hline 3. & $\begin{array}{l}\text { Mahasiswa menulis mufrodat dari video yang } \\
\text { didengar }\end{array}$ \\
\hline 4. & $\begin{array}{l}\text { Mahasiswa menceritakan kembali isi video dengan } \\
\text { bahasa arab }\end{array}$ \\
\hline 5. & $\begin{array}{l}\text { Mahasiswa mengungkapkan hikmah dari video } \\
\text { dengan bahasa arab }\end{array}$ \\
\hline
\end{tabular}

Kedua, Evaluasi. Dalam penelitian ini terbagi dua : pertama, tes tulisan/ tahriry (mahasiswa mengumpulkan catatan mufrodat hasil menyimak), kedua, tes lisan/ syafahy (mahasiswa secara langsung berbahasa arab dalam memberi kesimpulan dan hikmah dari video). Pada tes tahriry, pada dasarnya mengalami peningkatan dibandingkan sebelumnya. Akan tetapi persentase antara mahasiswa dengan mahasiswi masih terlihat mencolok. Hasilnya lebih tinggi mahasiswi dibandingkan mahasiswa. Padahal, jika ditelaah kembali mahasiswa memiliki kompetensi yang cukup. Namun, karena minatnya lebih besar mahasiswi maka mempengaruhi persentase hasil tes yang dijelaskan dengan diagram dibawah ini. 


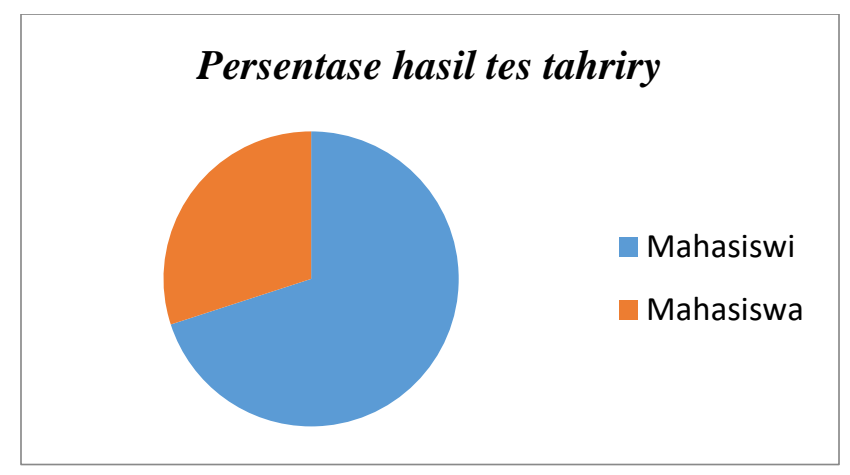

Sedangkan tes syafahy, dengan minimnya penggunaan bahasa arab secara langsung maka, dengan adanya metode Audio-visual dengan proses pembelajaran yang sudah terencana, sehingga mengalami peningkatan yang signifikan. Demikianlah proses pembelajaran dengan cara mengimplementasikan metode Audio-visual pada mahasiswa semester tiga pendidikan bahasa Arab di institut agama islam bani fatah jombang sudah terlihat ada perubahan ke arah yang lebih baik.

Dari hasil observasi, ditemukan beberapa kekurangan dalam sebuah pembelajaran terlebih pada pembelajaran istima'. Dengan kurangnya fasilitas yang memadahi, seperti laboratorium bahasa, maka pembelajaran dianggap kurang efektif. kondisi lapangan sangat berbeda dengan konsep yang dikemukan oleh Abdul Wahab Rosyidi (2009: 84) bahwa menyimak (al-istimā') adalah menuntut adanya kesengajaan dan perhatian dalam mendengarkan segala sesuatu, dan mendengar dengan serius (al-inșāt) adalah tingkatan lebih di atas menyimak yang menuntut konsentrasi dan perhatian yang lebih pada pembicaraan si penutur. Sehingga dengan berbekal fasilitas yang ada, seorang pendidik ditegaskan untuk bisa menerapkan metode yang dapat meningkatkan minat belajar dan keaktifan mahasiswa di kelas. Dengan demikian peneliti mengimplementasikan metode Audio-visual agar 
mahasiswa bisa menangkap pesan (istima') dengan baik dan juga dapat mengekspresikan dengan menggunakan bahasa arab yang baik (kalam).

Definisi yang dipaparkan oleh Siti Maesaroh (2013: 155) bahwa metode pembelajaran merupakan suatu alat pelaksanaan pendidikan yang digunakan dalam menyampaikan materi. sedangkan Audio visual adalah video yang menampilkan bentuk suara dan gambar (Lidya Fita Kusumadewi \& S. Suharto, 2010: 2).

Setelah peneliti melakukan observasi dan mengimpelementasikan langsung metode audio-visual pada pembelajaran istima` pada mahasiswa bahwa terlihat jelas perubahan yang cukup signifikan dalam aspek keaktifan mahasiswa dalam mengikuti proses pembelajaran ini. Sebagaimana hasil observasi awal peneliti bahwa pembelajaran istima' yang sebelumnya hanya menggunakan metode ceramah dan menggunakan media pengeras suara sebagai berikut: 1) mahasiswa kurang aktif dalam mengikuti proses pembelajaran. 2) mahasiswa terlihat jenuh dan bosan saat mengikuti proses pembelajaran. 3) mahasiswa enggan berinteraksi dengan dosen karena mereka tidak faham dengan apa yang diinstruksi dosennya. 4) mahasiswa kebingungan dalam mendengarkan audio karena mereka harus menulis mufradat yang sulit.

Oleh karena itulah, peneliti mencoba menarik kembali perhatian dan keaktifan mereka dengan cara mengimplementasikan metode audio-visual. Sebagaimana hasil penelitian di atas bahwa terlihat jelas perubahan sikap ataupun tingkah laku mahasiswa ketika mengikuti proses pembelajaran dengan menggunakan metode audio-visual. Sebagaimana yang ditegaskan oleh Arsyad, (2014: 4) bahwa media pembelajaran interaktif merupakan sistem penyampaian pengajaran yang menyajikan materi video rekaman dengan pengendalian komputer kepada penonton (peserta didik) yang tidak hanya pasif mendengar dan melihat video dan 
suara, tetapi juga aktif memberikan respon, dan respon peserta didik tersebut akan menentukan kecepatan dan sekuensi penyajian materi.

\section{Kesimpulan}

Untuk mencapai tujuan pembelajaran yang diinginkan maka perlu banyak trobisan yang dilakukan dosen dalam mengajar baik penerapan metode, penggunaan media, atau strategi pembelajaran. Apalagi terkesan menoton dan tidak menarik ini akan menyebabkan tujuan pembelajaran tidak akan tercapai dengan baik. Telebih-lebih di era modern ini penggunaan metode ataupun media pembelajaran yang variatif sangat dibutuhkan oleh dosen dan mahasiswa karena terkesan menarik dan sangat sederhana untuk digunakan. Sehingga pengalaman baru yang mereka dapati selama proses pembelajaran dan materi-materi yang telah disampaikan mudah mereka ingat dan dimengerti.

Implementasi metode audio-visual pada mahasiswa semester tiga pendidikan bahasa Arab di Institut Agama Islam Bani Fatah Jombang yang telah dilakukan oleh peneliti sudah memberikan perubahan baik aspek kognitif, afektif dan psikomotorik. Karena mahasiswa merasa terbantu dan mudah memahami materi istima' yang diperdengarkan kepada mereka. Yang mana materi yang mereka pelajari boleh dikatakan lumayan banyak sehingga jika diukur dengan waktu yang diberikan tidak akan cukup untuk menuntaskannya. Oleh karena itulah, metode audio-visual merupakan salah alternatif yang sangat bisa diterapkan sehingga materi yang disampaikan lebih muda difahami dan tidak membingungkan para mahasiswa. Mudah-mudahan tulisan yang sederhana ini dapat menambah wawasan peniliti dan pembaca. 


\section{Daftar Pustaka}

Aditya, Dedy Yusuf. 2016. Pengaruh Penerapan Metode Pembelajaran Resitasi Terhadap Hasil Belajar Matematika Mahasiswa .Jurnal SAP Vol. 1 No. 2 Desember 2016.

Afandi, Muhammad \& Evi Chamalah \& Oktarina Puspita Wardani. 2013. Model dan Metode Pembelajaran di Sekolah. Semarang. UNISSULA Press.

Ahmadi, Abu \& Joko Tri Prastya. 2005. Strategi Belajar Mengajar, Bandung: CV Pustaka Setia.

Alamsyah, Maurizal. 2009. Kiat Jitu Meningkatkan Prestasi dengan Mind Mapping. Yogjakarta. Mitra Pelajar.

Arsyad, A. 2014. Media Pembelajaran. Jakarta. Rajawali Pers.

Azizah, Sulis Nur. 2015. Penerapan Metode Mind Mapping Siswa Kelas V SD Negeri Jomblangan Banguntapan Bantul. Skripsi Program Studi Pendidikan Guru Sekolah Dasar Jurusan Pendidikan Pra Sekolah Dan Sekolah Dasar Fakultas Ilmu Pendidikan Universitas Negeri Yogjakarta.

Dasopang, Muhammad Darwis. 2017. Belajar dan Pembelajaran. FITRAH Jurnal Kajian Ilmu-Ilmu Keislaman. Vol. 03 No. 2 Desember 2017.

Ginting, Abdurrahman. 2008. Esensi Praktis Belajar dan Pembelajaran, Bandung: Humaniora.

Hamid, M. Abdul, dkk. 2008. Pembelajaran Bahasa Arab: Pendekatan, Metode, Strategi, Materi, Media. Malang. UIN Malang Press.

Hermawan, Acep. 2011. Metodologi Pembelajaran Bahasa Arab. Bandung. Remaja Rosdakarya. 
Kamus Besar Bahasa Indonesia (https://kbbi.web.id/metode. Diakses pada tanggal 25 November 2018 pukul 22.07).

Khalilullah, M. 2013, Media Pembelajaran Bahasa Arab, Yogyakarta. Aswaja Presindo.

Kusumadewi, Lidya Fita \& S. Suharto. 2010. Peningkatan Hasil Belajar Seni Musik Dengan Media Audio.

Maesaroh, Siti. 2013. Peranan Metode Pembelajaran Terhadap Minat Dan Pretasu Belajar Pendidikan Agama Islam. Jurnal kependidikan, Vol. 1 No. 1 Nopember 2013.

Mas'ud, Muhammad. 2014. Membuat Multimedia Pembelajaran dengan Lectora, cet.ke-3. Yogyakarta. Pustaka Shonif.

Mufid, Miftahul. 2018. Efektifitas Pemanfaatan Software Beesmart Untuk Tes Ketrampilan Istima' dan Qira'ah. AlMurabbi. Vol. 5. No. 1.

Munawwir, Ahmad Warson. 2002. al-Munawir Kamus Arab-Indonesia. Surabaya. Pustaka Progressif.

Nurseto, T. 2011. Membuat Media Pembelajaran yang Menarik. Jurnal Ekonomi \& Pendidikan, 8(1).

Republik indonesia, Undang-Undangn Republik Indonesia Nomor 20 Tahun 2003 Tentang Sistem Pendidikan Nasional.

Rosyidi, Abdul Wahab. 2009. Media Pembelajaran Bahasa Arab. Malang. UIN Malang Press.

Rusman, dkk. 2011. Pembelajaran Berbasis Teknologi Informasi dan Komunikasi Mengembangkan Profesionalitas Guru. Jakarta. PT Raja Grafindo Persada.

Sadiman, A.S. 1996 . Media Pendidikan Pengertian, Pengembangan dan Pemanfaatannya. Jakarta. PT. Raja Grafindo Persada. 
Sanjaya, Wina. 2008. Strategi Pembelajaran Berorientasi Standar Proses Pendidikan, Jakarta: Kencana Prenada Media Group.

Sudjana, Nana. 2002. Penilaian Hasil Proses Belajar Mengajar. Bandung. PT Remaja Rosdakarya.

Sumiati. 2008. Metode Pembelajaran. Bandung. CV Wacana Prima.

Vindayani, Fika. 2019. Strategi Belajar Bahasa Arab Mahasiswa Menurut Model Oxford. Prosiding Konferensi Nasional Bahasa Arab V. Jurusan Sastra Arab Fakultas Sastra Universitas Negeri Malang.

Wiliasari, Helina Fenty Ayu Ari. 2010. Penerapan model PAIKEM Gembrot dalam Pembelajaran Mengapresiasi Karya Seni Rupa Terapan Nusantara Untuk Meningkatkan Proses dan Hasil Belajar Kelas x 2 Sma negeri 1 Durenan Trenggalek Semester Genap 2010/2011. Universitas Negeri Malang.

Yovan, P. 2008. Memori dan Pembelajaran Efektif. Jakarta. Yrama widya.

Zulhanan, 2014. Teknik Pembelajaran Bahasa Arab Interaktif. Jakarta. Rajawali Pers. 
